\title{
Global Migrations and Turkey
}

\author{
DOI: 10.26466/opus.833619
}

\begin{abstract}
Bora Balun*
* Asst. Prof. Dr., Karabuk University Facult of Economics and Administrative Sciences

E-Mail: borabalun@karabuk.edu.tr ORCID: 0000-0002-4933-2271
\end{abstract}

\begin{abstract}
Today's migration movements have shifted to another line compared to the pre-modern age. Migration movements have been dragged into a great change in terms of both quantitative and qualitative aspects especially with the transnational nature of migration movements reaching an unpredictable scale and limiting the possibility of predicting the effects a raised. In parallel with this process, due to the fact that globalization movements have become more intense and as this movement naturally differentiates migration from the past, the country of origin and destination countries were affected socio-economically, and the demographic characteristics of migrants have begun to change. Moreover, migrations resulting from wars and internal conflicts have become a factor that directs migration movements by giving $d y-$ namism and that is as effective as globalization. In this study carried out based on the literature, current trends related with the migrations will be analyzed through Turkey and World sample; and in the analysis made over both Turkey and the World, periodic differences will be discussed through national and international reports and publications. At the same time, the whole work will be tried to be connected with the current and active position of Turkey in terms of international migrations, and the answers to the question that Turkey is a transit or target country for the foreign migrants will be sought.
\end{abstract}

Keywords: Global migration, Turkey, Foreign migrant. 
ISSN: 2528-9527

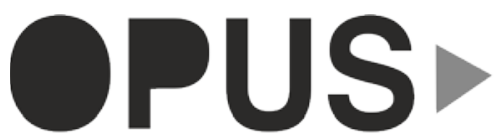

E-ISSN : 2528-9535

Yıl Year: 11

Cilt Volume: 17

Sayı Issue:36

Uluslararası Toplum Araştırmaları Dergisi

International Journal of Society Researches

Nisan Apri/ 2021

Makalenin Gelis Tarihi Received Date. 30/11/2020

Makalenin Kabul Tarihi Accepted Date. 06/04/2021

\section{Küresel Göçler ve Türkiye}

\section{Öz}

Günümüz küresel göç hareketleri, modern dönem öncesine oranla farklı bir çizgiye kaymıştır. Özellikle, göç hareketlerinin sınır aşan niteliğiyle öngörülemeyen bir ölçeğe ulaşması ve ortaya çıkan etkilerin tahmin edilme olasılı̆̆ının sinırlanmasıyla, göç hareketleri nicel ve nitel açıdan büyük bir değişime sürüklenmiştir. Bu sürece paralel olarak küreselleşme hareketlerinin şiddetlenmesi ve bu akımın doğal olarak göçleri geçmişe göre farklılaştırmasıyla menşei ülke ve hedef ülkeler sosyo-ekonomik açıdan etkilenmiş, göçmenlerin demografik özellikleri de değişmeye başlamıştır. Ayrıca savaşlar ve iççatışmalar sonucu ortaya çıkan göçler de göç hareketlerine dinamizm kazandırtp yön veren ve küreselleşme kadar etkili bir unsura dönüşmüştür. Literatüre dayalı olarak gerçekleştirilen bu çalışmada, Dünya ve Türkiye örneği üzerinden göçlere dair güncel eğilimler analiz edilmeye çalışllacak gerek Dünya, gerekse de Türkiye üzerinden yapılan analizde dönemsel farklar ulusal ve uluslararası rapor ve yayınlar aracılığıyla tartışılacaktır. Aynı zamanda çalışmanın bütünü Türkiye'nin uluslararası göçler açısından güncel ve hareketli konumuna bağlanmaya çalışılacak ve Türkiye'nin yabancı göçmenler açısından transit ülkemi yoksa hedef ülkemi olduğu sorusunun yanttı aranacaktır.

Anahtar Kelimeler: Küresel Göç, Türkiye, Yabancı Göçmen 


\section{Introduction}

With the strengthening of the globalization dynamics and the fact that a large number of people and therefore countries have started taking part in the international migration movements, recent migration movements have changed a great deal. As an inevitable result of this situation migration movements have differentiated in many ways compared to the past. In particular, developments in the production technologies have increased the demand for the labour-centred workforce. In addition, inequalities created by wars and internal conflicts, religious pressures, sexist approaches have become a driving force shaping the migration phenomenon of the globalizing world. At the same time, demographic characteristics of migration movements started to change due to the reasons such as diversification of the need for the work-force, and the increase in the demand for female workers for domestic services with the increase in the elderly population. Naturally these and similar developments have created a large population with the tendency for migration. At this point, the approach the migrants choose when moving to the target country could be legal, illegal or could be the mixture of both methods. The migration routes that are generally preferred are the USA and European centered. For example, hundreds of thousands of migrants move to Europe through the West Africa Route, West Mediterranean Route, Middle Mediterranean Route, Eastern Route, West Balkan Route, Black Sea Route, East Border and Circular Routes of Greece and Albania (Şişman and Balun, 2020, p. 66-67). On the other hand, Mexico and Canada land borders used to reach The United States of America and other sea borders constitute the important center of the migration issue. This development causes the diversification and the increase of both the target and the source countries located in different geographies. However, socio-economic effects created by the migrations in the target country in time reveal the idea that these movements should be managed. The approaches emerged could vary according to the features of the migration and the way countries handle the situation. For example, countries with security-centered approach for the migration movements can have strict border security policies; countries giving priority to political and/or economic preferences can have more different border security approaches. 
Turkey, with its bridge-like location between Europe and Asia, is an important stopping point for migrants who want to go to Europe from Africa, Middle East and Asia through illegal ways and at the same time it is the target country where they permanently settle down. In other words, for some migrants Turkey is a country of transit, which they use to pass through to reach the target country and for some migrants it is the target country where they continue to live. Therefore, Turkey has become the country where foreign migrants migrate to or intensely use as a transit migration base as well as protecting its characteristics of being a country that is recently migrated from. In fact, when the migration flows of the Republic Period are examined, a country profile that has experienced different processes emerges. In the first years of the Republic, under the scope of modernization movements, a homogenous society was aimed and there seemed no extraordinary dynamism in migration movements. It can be said that Refugee-based limited migration movements shaped the era after the World War II. In 1980s it is possible to mention migration movements although they were not so big as to create socio-political debate (İçduygu, Sert and Karaçay, 2009, p. 1). But recently Turkey has become a migrant receiving country rather than sending country. Although there are quite a few background developments, especially Syria oriented migrations and irregular migrations are the basic points shaping this phenomenon (Düvell, 2018, p. 1). For instance, as of 2020 there are nearly 4 million refugees in Turkey. In 2018, the number of illegal migrants to Europe was 150.114. When looking into the nationalities of these migrants, the first three were Syria (14.378 migrants), Morocco (13.269 migrants), and Afghanistan (12.666 migrants). When considering the distributions of the illegal migrations realized in 2018, it is stated that 56.561 illegal migrants used the Turkey-centered East Mediterranean Route. This number makes the $1 / 3$ of the total transitions in 2018 (Frontex, 2019). In the studies and reports by İçduygu, (2005 pp. 1), İçduygu and Yükseker, (2010, p. 443), Wissink, Düvell, and Eardewijk, (2013, p. 1088-1089), International Organization for Migration, (2017, p. 1118), it is especially emphasized that geographical and political location of Turkey is the main factor shaping the regular and irregular migration as well as transit migrations. And the human mobility raised related with this situation continues to create socio-economic effects in Turkey. 


\section{General View in Migration Flows: World General}

Migration is a universal phenomenon that arises in all societies and at all times, mostly emerging under the influence of determinants such as vital needs and environmental conditions. It can be said that generally geographical conditions such as famine and climate; and political reasons such as wars and border issues were effective in the migration movements that continued until the Industrial Revolution. But the industrialization process has changed the classical patterns of the migration. In fact, with the effect of the requirements caused by the process, cities have grown and technology started to develop at an extraordinary speed. Industrialization, urbanization and technology-oriented development process have revealed the globalization phenomenon resulting in societies getting closer to each other and integration in economic, political, communication and social aspects.

Especially since the second half of 1970, the globalization phenomenon, which is felt more and more, has led to radical changes in societies by expanding the factors causing migration. At the same time, together with the effect of this process individual and social needs, preferences and expectations have also started to change. This transformation emerged in the social structure has further developed the idea of living better; moreover, it has also affected the cultural, economic and political tendencies. Therefore, migration concepts and migration decision processes have also been affected by these developments in social tendencies. Together with the new process emerged with the migration, principles such as freedom, career, income and employment, education have become central to the determinants of migration. But it is claimed that these changes in the quality and quantity characteristics of the migration are still continuing. Together with the effects created by the globalization process, it is possible to see that the issues like more and more countries involving in the migration movements; the idea that economic, politic and cultural effects created by migration should be managed becoming more clear; and the changes happening in the migration demographics (especially women integration in the migration process and increase in their effects) are among the approaches developed to explain this process. 
These facts have also caused changes in the effects of migration and revealed different characteristics unique to themselves in migration movements. These differences emerged either from the personal characteristics of the individual such as knowledge, skills, education or from the economic and social structure of the migrated country. Because the differences orienting from the places migrated from and the person migrating can cause a social change at the same time, it is necessary to analyze the migration mechanics and the characteristics belonging to the effects of migration. However, this subject has started to be examined in more detail because of the recent increase in the international migration. Because, the findings indicating that migrant mobility and therefore the number of the migrants will continue to increase and constitute an important reference point.

For instance, according to the data in the United Nations reports, it was calculated that in 1970, 85 million people lived in other countries other than where they were born. Moreover, in the following years the number of international migrants have increased consistently. Hence, although the ratio of the number of the international migrants to the world population was $2,3 \%$ in 1970 , this ratio reached $3.2 \%$ by the 2000 s and $3.5 \%$ as of 2019 (Table 1). When looking into the tendencies of the migrations across regions, it is seen that the number of international migrants worldwide increased by approximately 119 million in the periods between 1990 and 2019. In this period, the number of international migrants heading to the developed countries was 69 million and the number of those heading to the less developed countries was 50 million (United Nations, 2018; United Nations, 2019). From a broader perspective, only in 2019, the number of international migrants in 2019 increased approximately 3 times compared to 1970 and reached 272 million. According to these numbers it is understood that approximately 4 out of 100 people are migrants. In other words, when 272 million migrants are considered all together, it is understood that it has the capacity to form the 5th largest country in the world after China, India, the USA and Indonesia. 
Table.1. International Migrants (1970-2019)

\begin{tabular}{lll}
\hline Year & The number of migrants & Ratio of international migrants to the world population (\%) \\
\hline $\mathbf{1 9 7 0}$ & 84.460 .125 & $\% 2.3$ \\
\hline $\mathbf{1 9 7 5}$ & 90.368 .010 & $\% 2.2$ \\
\hline $\mathbf{1 9 8 0}$ & 101.983 .149 & $\% 2.3$ \\
\hline $\mathbf{1 9 8 5}$ & 113.206 .691 & $\% 2.3$ \\
\hline $\mathbf{1 9 9 0}$ & 152.563 .212 & $\% 2.9$ \\
\hline $\mathbf{1 9 9 5}$ & 160.801 .752 & $\% 2.8$ \\
\hline $\mathbf{2 0 0 0}$ & 172.703 .309 & $\% 2.8$ \\
\hline $\mathbf{2 0 0 5}$ & 191.269 .000 & $\% 2.9$ \\
\hline $\mathbf{2 0 1 0}$ & 221.714 .243 & $\% 3.2$ \\
\hline $\mathbf{2 0 1 5}$ & 243.700 .236 & $\% 3.2$ \\
\hline $\mathbf{2 0 1 9}$ & 272.000 .000 & $\% 3.5$ \\
\hline
\end{tabular}

International Organization for Migration, 2020; United Nations, 2019.

When looking into the grouped distribution of the international migrants, the largest group with 150.3 million people consists of those with the status of migrant workers. Irregular migrants (50 million), registered refugees (25,4 million) and forced labour (25 million) follow this group respectively. Another considerable data among these is related with the international students. There are 4.8 million people in this group and they are approaching the population of an average Scandinavian country (like Denmark) (Table 2).

Table.2. Grouped Distributions of International Migrants

\begin{tabular}{lll}
\hline Status & Number & Year of data \\
\hline Migrant worker & 150,3 million & 2015 \\
\hline International student & 4,8 million & 2016 \\
\hline Irregular migrant $^{1}$ & 50 million & 2009 \\
\hline Refugee (Registered) $^{\prime}$ & 25,4 million & 2017 \\
\hline Refugee (Accepted) & 102 thousand & 2017 \\
\hline Migrants who lost their lives during migration (At least and for 2017) & 6 thousand & 2017 \\
\hline Forced labour (Estimated) & 25 million & 2016 \\
\hline Volunteer Returning & 72 thousand & 2017 \\
\hline
\end{tabular}

International Organization for Migration, 2020.

Mass migration movements affect the socio-cultural structure, demographic characteristics and economies of the cities deeply. In parallel with the spatial and cultural changes with the effect of mass migration flows, significant changes have been experienced in the areas of employment, labor

\footnotetext{
1 Irregular migrants are those who have entered a country duly without a document prepared by official authorities or without permission, or stay over the allowed period. It is very difficult to determine the true number of irregular migrants (United Nations, 2013, pp. 7-19).
} 
force, city management and income distribution in the cities receiving migration.

When the data in the reports are examined, it can be said that wars, internal conflicts and political instabilities also have an important impact on migrations. For instance, in the reports published by international organizations, Syria-oriented migrations are considered among the great mass $\mathrm{mi}-$ gration cases. Another issue apart from the Syria-oriented migration is the migrations oriented from Middle East and African countries such as Iraq, Iran, Afghanistan, Yemen and Egypt. According to the data from the United Nations Refugee Organization in 2017, the population that was displaced due to cruelty, clashes, or general violence has reached 68,5 million (Table 3) (United Nations High Commissioner for Refugees, 2017, pp. 2-3). When looking into the distribution of the migrations oriented from Middle East and African countries, it is understood that they consist of the $38 \%$ of the new worldwide migrations in 2017 occurred due to clashes and violence. When considered on the scale of the world population, it shows that one in every one hundred and twenty people on earth is forcibly displaced.

Table. 3. Forced Displacement Population (2017)

\begin{tabular}{ll}
\hline Refugee & $\mathbf{2 5 . 4}$ million \\
\hline Displaced person (in their own countries) & 40 million \\
\hline Asylum seeker & 3.1 million \\
\hline
\end{tabular}

United Nations High Commissioner for Refugees, 2017.

When some more specific details of the global migration trends are looked into, it is seen that child migrants consisted $14 \%$ of the international migrants in 2017. According to the United Nations Department of Economic and Social Affairs, the estimated number of individuals aged 19 or younger who are living in a country other than their country of birth increased up to 36 million with a $21 \%$ increase rate in 2017 . Moreover, there has been a significant increase in the number of unaccompanied migrant children recently. The estimated number of children migrating alone in 2015-2016 is five times as much as in 2010-2011. The number of unaccompanied children or those separated from their families applying for asylum outside the European Union increased from 4.000 in 2010 to 19.000 in 2015. According to Eurostat, the number of unaccompanied children among the refugees in Eu- 
rope increased from 10.610 in 2010 to 95.208 in 2015, but this number decreased down to 63.280 in 2016 . When the situation of women migrants is looked into, it is seen that $48,8 \%$ of the international migrants consist of women in 2017. The ratio of women migrants decreased from 49,1\% in 2000 to $48,4 \%$ in 2017 . However, the ratio of women migrants according to regions changes a great deal and since 2000 the ratio of women migrants has in fact increased slightly in all regions except Asia (United Nations, 2018, p. 42).

When other indicators relevant to the issue are considered, the number of irregular migrants kidnapped in order to generate income in 2016 was about 2,5 million. Estimated amount of the economic gain generated from these activities is calculated as about 5,5-7 billion US Dollars. It was calculated that, in 2015, 66 million adults (or 1,3\% of the adult population in the world) were planning to settle down permanently in another country. Within the scope of migration, the amount of aid provided to Countries with Low and Middle Income in 2017 was 466 Billion Dollars (International Organization for Migration, 2020).

As the world population increases, consumption also increases and the impacts of climate changes become clearer. All these challenges increase the pressure on many countries and require compromise with other countries in the solution of these problems. After all, these problems have the capacity to affect present situation both in affected countries and their neighbors negatively. It is expected that nearly 1 billion people or ten percent of the world population will be displaced because of natural disasters and armed clashes in the next 30 years. Therefore, it is necessary to determine to what extent countries will be affected by these movements and what their capacity to respond to extreme shocks is. In fact, international studies show that ecological threats ${ }^{2}$ will expand the frame of the population movements in the world and will cause significant population displacement. Within this respect, it is seen that the number of natural disasters has tripled in the last forty years. At the same time 2,4 billion people living in countries with water shortage have problems in accessing fresh water. It is expected that this

\footnotetext{
2 Population increase, water scarcity, food insecurity, droughts, floods, cyclones, and increase in the heat and sea level is meant with the term ecological threat.
} 
continuously increasing number to reach 5,4 billion in 2040 . When it is considered that the global population will increase $25 \%$ in the next 30 years, this table will be more complicated (Table. 4) (The Institute for Economics and Peace, 2020, p. 8).

Table 4. General View (Ecological Threat)

\begin{tabular}{|c|c|}
\hline Fact & Impact \\
\hline $\begin{array}{l}\text { The number of the individuals exposed to middle or } \\
\text { high levels of ecological threats. }\end{array}$ & 6.4 billion persons \\
\hline $\begin{array}{l}\text { The number of the countries exposed to at least one } \\
\text { ecological threat }\end{array}$ & 141 \\
\hline $\begin{array}{l}\text { The number of the countries exposed to four or more } \\
\text { threats. (ecological, lack of sources, conflicts, food se- } \\
\text { curity, water shortage) }\end{array}$ & 19 \\
\hline $34 \%$ of the 157 countries to face ecological threats. & $\begin{array}{l}\text { It is expected that high level water shortage is ex- } \\
\text { pected until } 2050 \text {. }\end{array}$ \\
\hline $22 \%$ of the 157 countries to face ecological threats. & It is expected that they will face food insecurity \\
\hline $\begin{array}{l}\text { Number of people estimated to be displaced due to } \\
\text { ecological threats and armed clashes by the year } 2050\end{array}$ & More than one billion people \\
\hline Floods & $\begin{array}{l}\text { The most common ecological threat affecting the } \\
60 \% \text { of the countries in the report. }\end{array}$ \\
\hline $\begin{array}{l}\text { The second threat after the floods that will affect } 43 \\
\% \text { of the countries by the year } 2040 \text { is }\end{array}$ & Water shortage \\
\hline
\end{tabular}

Compiled from The Institute for Economics and Peace, 2020, p. 7.

Table 5 shows grouping of countries by regional views (ecological threat). In the world, countries where wars and internal conflicts are experienced, that is countries where social peace is unstable are among those where food insecurity ${ }^{3}$ is the most intense. For instance, the fact that quite a few people faced hunger in Yemen in 2020 is among the evidence of this situation. Moreover, $65 \%$ of the population in countries where wars and internal conflicts are intense and the level of income is low have great problems in nutrition and reaching healthy food. $16 \%$ of the population even in OECD countries do not have financial opportunity to get food regularly and $2,7 \%$ are undernourished. This situation underlines the reality that even the population in rich countries are under the risk of food insecurity. When the impacts of ecological threats are taken into consideration at the regional

3 Food insecurity is defined as the deterioration of food intake or eating habits due to lack of money and other resources (Nord, Andrews and Carlson, 2006, p. 6). 
level, Middle East and North Africa are the regions where food scarcity is the greatest threat and the estimates show that this situation will get worse in the next 20 years. It is stated that 33 of the 43 countries in Sub-Saharan Africa are exposed to middle and high levels of ecological threats (The Institute for Economics \& Peace, 2020).

Table 5. Regional Views (Ecological Threat)

\begin{tabular}{ll}
\hline Fact & Impact \\
\hline $\begin{array}{l}\text { 10 of the } 19 \text { countries exposed to the ecologi- } \\
\text { cal threats most }\end{array}$ & $\begin{array}{l}\text { Among the } 40 \text { countries where internal conflicts are } \\
\text { intense according to the Global Peace Index }\end{array}$ \\
\hline $\begin{array}{l}\text { Regions facing quite a lot of ecological } \\
\text { threats }\end{array}$ & $\begin{array}{l}\text { Sub-Saharan Africa, South Asia, Middle East and } \\
\text { North Africa }\end{array}$ \\
\hline $\begin{array}{l}\text { 33 of the } 43 \text { countries in the Sub-Saharan Af- } \\
\text { rica }\end{array}$ & $\begin{array}{l}\text { They expose to middle and high level of ecological } \\
\text { threats }\end{array}$ \\
\hline $\begin{array}{l}\text { Regions where water shortage is the greatest } \\
\text { threat }\end{array}$ & $\begin{array}{l}\text { The Middle East and North Africa are at great risk. } 18 \\
\text { of the } 20 \text { countries experience high level of water } \\
\text { shortage (It is estimated that the situation will worsen } \\
\text { in two decades) }\end{array}$ \\
\hline $\begin{array}{l}\text { Regions to face lower level of ecological } \\
\text { threats }\end{array}$ & $\begin{array}{l}\text { Majority of the countries in Europe and South Amer- } \\
\text { ica }\end{array}$ \\
\hline
\end{tabular}

Compiled from The Institute for Economics \& Peace, 2020, p. 7.

Although Sub-Saharan Africa, and Middle East and North Africa are shown among the countries exposed to middle and high level of ecological threats, there are fewer number of countries when compared to Europe and South America in terms of middle and high level of threats. Europe is also the region with the largest concentration of countries that is not exposed to high-intensity ecological threats (Table.6) (The Institute for Economics \& Peace, 2020, p. 13). 
Table.6. Grouping of Countries by Risk Level (Ecological Threat)

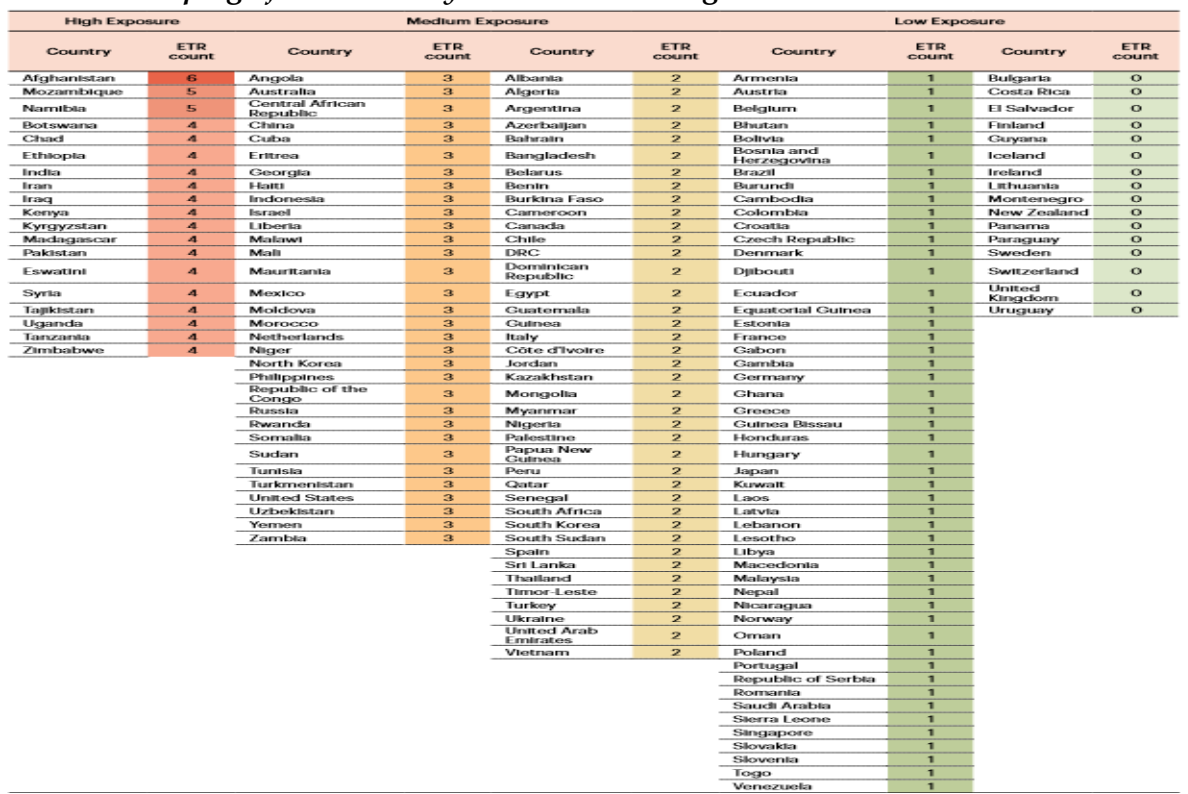

The Institute for Economics \& Peace, 2020, p. 11.

\section{General View in Migration Flows: Turkey}

\section{Regular Migrations}

With the concept of regular migration, in accordance with the criteria in the framework of the law and legislation, human movements coming from abroad and entering through official border gates are defined. Migrants who want to migrate officially are expected to have residence, education and work permits. Basically, this kind of permits are considered the main components of the regular migrations. Within this respect, 6.428 .514 people got their residence permits in the 2005-2020 period (Table 7). However, it is remarkable that $1 / 3$ of this number has been reached in the last two years. When the details of the data are examined, it is understood that approximately $20 \%$ of the regular migrants get their residence permits in order to work and study. When the general characteristics of this group being in Turkey with different reasons are considered, regular migrants who want to get residence permit in order to work should in fact get a work visa beforehand. Migrants who 
fulfill the necessary conditions can work temporarily, permanently or independently. Foreigners with an approved application can get a temporary work permit provided their employment or service contract is not expired or they work in certain workplaces belonging to natural or legal persons; at public institutions or in a specific job. Temporary work permits can be granted for only one year. Provided that it is applied duly, maximum two years of work permit is granted for the first work permit extension application with the same employer. With the same conditions and with the same employer, maximum a three-year work permit is granted for the other extension applications. With different employers, principles for the first application are implemented and a maximum one-year work permit is granted (International Labour Law, Article 10/1; Article 10/2). Indefinite work permit is an application developed for foreigners to enable them to work for one or more years. Provided that the rights of foreigners who were granted an indefinite work permit before 11.4.2014 are reserved, it is granted to those who have a longterm residence permit in accordance with the Foreigners and International Protection Law No. 6458 and the International Labour Force Law No. 6735. At the same time this permit can be granted to the foreigners who lived in Turkey for at least eight uninterrupted years with the residence permit and who had at least 8 year-legal work. However, having such conditions does not give foreigners absolute right to work. Foreigners with the indefinite work permit do not have obligations such as voting, being elected, entering public services or performing military service (International Labour Law, Article 10/3; Article 10/4).

Independent work permit is an application developed for foreigners who have a profession. Independent work permits can be granted provided that conditions specified in other laws are met. One of the laws these conditions are referred to is International Labour Law No:6735. According to the law, there is a residence period limit in Turkey in order to get the independent work permit. Migrants to apply for this permit should be living in Turkey for five years legally and uninterruptedly. There is not a special regulation including a time restriction on how many years independent work permit can be granted. (International Labour Law, Article 10/6; Article 10/8). Family residence permit is an application regulated within the framework of Articles 34 and 37 of the Foreigners and International Protection Law \#6458. Family res- 
idence permit is granted to those who are under the scope of Turkish Citizenship Law \# 5901, Article 28, and to the spouses and children of refugees and subsidiary protection holders. Foreigners who are going to do their associate degree, bachelor's degree, masters or PhD in a higher education institution in Turkey are granted with student residence permit (Foreigners and International Protection Law, Article 38/1). When the changes over the years given in Table 7 are followed, the number of student residence permits appears to be increasing. While 25.240 students benefited from student residence permits in 2005, this number has increased approximately three times in 2020 and reached 83.372. Short-term residence permits cover slightly larger groups. For example, those to carry out scientific research, those owning real estate properties, those to make trade connections etc. can get benefited from short-term residence permits (Foreigners and International Protection Law, Article 33/1). Although we do not have consistent data about the short-term residence permits, it is possible to see positive trends in this number like other permits. While 202.403 people benefitted from this type of permit in 2015 , this number has increased three times in 2020 and reached 629.552.

Table.7. Regular Migrations (Resident Permits: 2005-2020)

\begin{tabular}{|c|c|c|c|c|c|c|c|c|c|c|c|c|c|c|c|c|}
\hline & 足 & ๕్రి & ڤ્ণి & ఫ్సి & ڤ్సి & ีㅗㄱ & $\overrightarrow{\text { สె }}$ & สี & तై & تี & జొ & 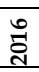 & $\widehat{\tilde{\text { สิ }}}$ & $\stackrel{\infty}{\tilde{\pi}}$ & ते & జิి \\
\hline 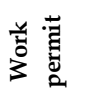 & 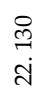 & $\begin{array}{l}\text { L } \\
\infty \\
\text { ה̇ं }\end{array}$ & 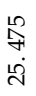 & 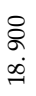 & 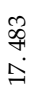 & $\begin{array}{l}\overrightarrow{5} \\
\text { o. } \\
\sigma\end{array}$ & 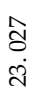 & & $\begin{array}{l}\text { 今े } \\
\text { ł. }\end{array}$ & $\begin{array}{l}\infty \\
0 \\
+1 \\
\infty \\
\end{array}$ & 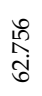 & 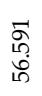 & 赵 & $\begin{array}{l}\hat{\infty} \\
\infty \\
\underline{\omega} \\
\vec{z}\end{array}$ & & \\
\hline 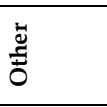 & 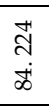 & $\begin{array}{l}\text { ते } \\
\text { हैं } \\
\text { ले }\end{array}$ & 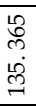 & $\begin{array}{l}\text { ฟे } \\
\text { Iิ }\end{array}$ & 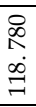 & 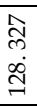 & $\begin{array}{l}\hat{\sigma} \\
\text { aे } \\
\text { है }\end{array}$ & & 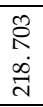 & 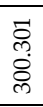 & 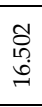 & $\begin{array}{l}0 \\
\text { o. } \\
\text { iे }\end{array}$ & & & & $\begin{array}{l}\text { ⿵人丶 } \\
\text { مी } \\
\text { ले }\end{array}$ \\
\hline 离 & & & & & & & & & & & $\begin{array}{l}\stackrel{2}{2} \\
\stackrel{1}{\alpha} \\
\end{array}$ & 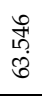 & & & & 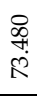 \\
\hline 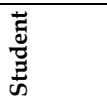 & $\begin{array}{l}\text { 연 } \\
\text { வ্ं }\end{array}$ & $\begin{array}{l}\stackrel{\infty}{\stackrel{2}{+}} \\
\stackrel{+}{+}\end{array}$ & $\begin{array}{l}\text { aे } \\
\text { ล் }\end{array}$ & $\begin{array}{l}\text { ôे } \\
\text { in } \\
\text { iे }\end{array}$ & $\begin{array}{l}\text { రి } \\
\text { הें }\end{array}$ & $\begin{array}{l}\text { तें } \\
\text { तें }\end{array}$ & 总 & & $\begin{array}{l}\text { o } \\
\text { : } \\
\text { in }\end{array}$ & $\begin{array}{l}\frac{1}{0} \\
\stackrel{0}{0} \\
\text { ర }\end{array}$ & $\begin{array}{l}\text { ते } \\
\text { مิ } \\
\text { }\end{array}$ & $\underset{7}{\stackrel{0}{7}}$ & & & & $\begin{array}{l}N \\
\text { N } \\
\infty \\
\infty\end{array}$ \\
\hline $\begin{array}{l}\text { 音 } \\
\text { ஸे }\end{array}$ & & & & & & & & & & & 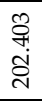 & $\begin{array}{l}\text { है } \\
\text { सं }\end{array}$ & & & & 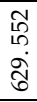 \\
\hline 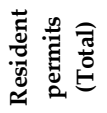 & 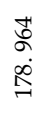 & 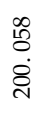 & $\begin{array}{l}\text { ते } \\
\text { तิ } \\
\text { ลे }\end{array}$ & $\begin{array}{l}\text { Lू } \\
\text { +் }\end{array}$ & $\begin{array}{l}\text { ले } \\
\text { लें } \\
\text { ర్ర }\end{array}$ & 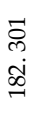 & 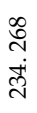 & 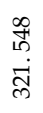 & $\begin{array}{l}\delta \\
\delta \\
\text { ले } \\
\text { ले }\end{array}$ & $\begin{array}{l}\text { पे } \\
\infty \\
\text { న. } \\
\text { }\end{array}$ & 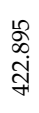 & तิ & $\begin{array}{l}\sqrt{n} \\
\stackrel{2}{0}\end{array}$ & 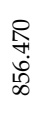 & $\begin{array}{l}0 \\
0 \\
\stackrel{0}{0} \\
\stackrel{0}{\rightarrow} \\
\end{array}$ & 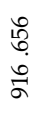 \\
\hline
\end{tabular}

Compiled from Directorate General of Migration Management, 2020;

Directorate General of Migration Management, 2016; Directorate General of Migration Management, 2015; Directorate General of Migration 
Management, 2014; Directorate General of Migration Management, 2013; Ministry of Family, Labour and Social Services, 2018; Ministry of Development, 2014. In determining the data for 2020, the date of 16.09 .2020 is taken as a basis. 2020 data are based on the Directorate General of Migration Management in the total number of residences permits between 2005-2011; detailed data are based on the 2014 publication of the Ministry of Development. When the table is combined, it is understood that there is a difference of approximately $10 \%$ between the detailed data and the grand total.

\section{Irregular Migrations}

The position of individuals involved in the international mobility in the migration system is classified according to the legal legislation of the host country. In particular, regulations and implementations of the host country related with the entry, residence or work permits define the legal status of the migrants. Persons lacking a legal status in the transit or host country because of illegal entry, breaching entry requirements or expiring validity period of the visas are defined as "irregular migrants". In the literature of migration, it is possible to see terms such as undocumented migrants, fugitive or illegal migrants instead of irregular migrants. Irregular migrants are basically three types: those who enter through borders through illegal ways, or those whose visa period has expired, or those who act contrary to their legal status although they have a tourist, residence or work permit. When the reasons that give rise to irregular migrant status are taken into consideration, it is seen that violation of the laws constitutes the main condition. Therefore, as there is an action based on the illegality, it is quite difficult to reach the quantitative and qualitative data of the illegal migrants in real terms.

Table 8 shows the number of irregular migrants caught in the 2005-2020 period. When the table is examined by dividing into five-year periods, it is observed that the number of irregular migrants caught in the first five-year period tends to increase except 2009. While the number of irregular migrants caught in 2005 was 57.428, this number increased to 65.737 in 2008 . However, it is understood that the number of irregular migrants apprehended decreased although there were numerical fluctuations during the period between 2009 and 2014. But 2015 and the following years mark the 
period when extraordinary jumps occurred in the number of irregular migrants apprehended. As a matter of fact, the number which was 58.647 in 2014 increased three times as much and reached up to 146.485 in 2015 . In 2019, this number was 454,662, which was three times as much as in 2015. When 2005, the starting year of Table 8 is compared with 2019, it is observed that an approximately 9 times increase in the number of irregular migrants apprehended.

Table.8. Irregular Migrations (2005-2020)

\begin{tabular}{ll}
\hline Year & The number of migrants \\
\hline $\mathbf{2 0 0 5}$ & 57.428 \\
\hline $\mathbf{2 0 0 6}$ & 51.983 \\
\hline $\mathbf{2 0 0 8}$ & 64.290 \\
\hline $\mathbf{2 0 0 9}$ & 65.737 \\
\hline $\mathbf{2 0 1 0}$ & 34.345 \\
\hline $\mathbf{2 0 1 1}$ & 32.667 \\
\hline $\mathbf{2 0 1 2}$ & 44.415 \\
\hline $\mathbf{2 0 1 3}$ & 47.510 \\
\hline $\mathbf{2 0 1 5}$ & 39.890 \\
\hline $\mathbf{2 0 1 6}$ & 58.647 \\
\hline $\mathbf{2 0 1 7}$ & 146.485 \\
\hline $\mathbf{2 0 1 8}$ & 174.466 \\
\hline $\mathbf{2 0 1 9}$ & 175.752 \\
\hline $\mathbf{2 0 2 0}$ & 268.003 \\
\hline
\end{tabular}

Directorate General of Migration Management, 2020a (In determining the data for 2020, the date of 16.09.2020 taken as a basis).

Since Turkey is geographically a bridge-like country between Europe and Asia, it has become both a target country in the irregular migration system and a transit migration base. Increase in the socio-economic differences, political instabilities, conflicts and wars, persistence of race, gender and religion-based oppression in the nearby regions, in particular in the border neighbors, has become consistent and therefore this has further strengthened this position of Turkey. In fact, when the migration flows towards Turkey in the 2014-2020 period in accordance with the source country, findings supporting this determination are reached. When Table 9 is taken into consideration, it is seen that countries like Syria, Afghanistan, Iraq and Pakistan, located in the east of Turkey, where instability is intense for various 
reasons, are among the countries with the highest number of irregular migrants. Therefore, Turkey faces irregular migrant flows being both target and transit country (Table.9).

Table.9. Source of Irregular Migration by Country

\begin{tabular}{|c|c|c|c|c|c|c|c|c|c|c|c|}
\hline & 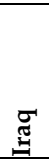 & 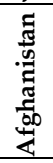 & 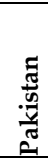 & 荧 & $\begin{array}{l}\frac{\tilde{z}}{0} \\
\frac{0}{0} \\
\frac{0}{2}\end{array}$ & 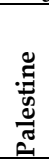 & 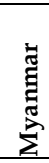 & 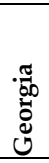 & ฐ & 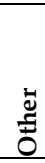 & $\begin{array}{l}\text { J } \\
\stackrel{0}{0}\end{array}$ \\
\hline ت્ّ & 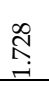 & $\begin{array}{l}\stackrel{8}{\mathbb{J}} \\
\mathbb{J}\end{array}$ & 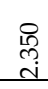 & $\begin{array}{r}\overrightarrow{0} \\
\text { oे } \\
\vec{d}\end{array}$ & $\stackrel{\Xi}{9}$ & $\begin{array}{l}\infty \\
0 \\
10\end{array}$ & 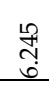 & हृे & ర్రి & $\begin{array}{l}\infty \\
\stackrel{n}{n} \\
\infty\end{array}$ & $\begin{array}{l}\text { fo } \\
\text { d. } \\
0 \\
0\end{array}$ \\
\hline ص్స & Â & 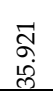 & 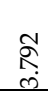 & $\begin{array}{l}\text { Fै } \\
\text { 促 }\end{array}$ & $\vec{d}$ & $\frac{10}{\vec{b}}$ & $\begin{array}{l}\text { t⿱ } \\
\text { of } \\
\text { r }\end{array}$ & 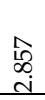 & 兽 & 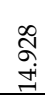 & 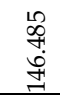 \\
\hline : & $\begin{array}{l}\text { के } \\
\text { कें } \\
\text { क्ष }\end{array}$ & 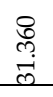 & $\begin{array}{l}\stackrel{\vec{m}}{\mathrm{~m}} \\
\stackrel{\vec{q}}{2}\end{array}$ & $\begin{array}{l}\text { 员 } \\
\text { ô } \\
0\end{array}$ & 륨 & 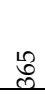 & $\stackrel{g}{\stackrel{G}{ت}}$ & $\begin{array}{l}\text { i. } \\
\text { i }\end{array}$ & 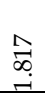 & 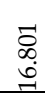 & $\begin{array}{l}0 \\
+1 \\
+1 \\
+1\end{array}$ \\
\hline స్ㅎ․ & 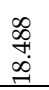 & $\begin{array}{l}\text { ầे } \\
\text { bु }\end{array}$ & $\begin{array}{l}\text { लि } \\
\text { o. } \\
\tilde{c}\end{array}$ & $\begin{array}{l}\overrightarrow{1} \\
\text { जे }\end{array}$ & $\stackrel{\infty}{\infty}$ & $\widetilde{\infty}$ & $\underset{c}{\mathbb{c}}$ & $\begin{array}{l}\text { 岁 } \\
\text { d }\end{array}$ & 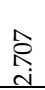 & 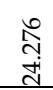 & 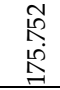 \\
\hline$\stackrel{\infty}{\stackrel{\sim}{*}}$ & స్ర్ & $\begin{array}{l}\vec{J} \\
\stackrel{0}{0} \\
\stackrel{0}{0}\end{array}$ & $\begin{array}{l}\infty \\
\text { ô } \\
0 \\
0\end{array}$ & $\begin{array}{l}\tilde{B} \\
0 \\
\dot{0} \\
0\end{array}$ & : & 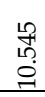 & $\stackrel{\substack{\infty \\
\varnothing}}{2}$ & 葛 & $\begin{array}{l}\stackrel{8}{\circ} \\
\end{array}$ & $\begin{array}{l}\overrightarrow{3} \\
\text { ర్t } \\
\vec{f}\end{array}$ & $\begin{array}{l}8 \\
8 \\
0 \\
0 \\
0\end{array}$ \\
\hline ڤ్సे & $\begin{array}{l}\hat{\text { oे }} \\
\text { di }\end{array}$ & 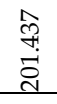 & 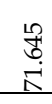 & 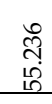 & ¿゙ & 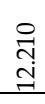 & ते & $\underset{\text { ㄱ. }}{\mathbb{N}}$ & 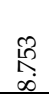 & $\begin{array}{l}0 \\
\text { : } \\
\text { \& }\end{array}$ & 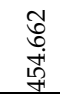 \\
\hline జ్రి & & $\begin{array}{l}\text {.े } \\
\text { is }\end{array}$ & $\begin{array}{l}\infty \\
\infty \\
\infty \\
\infty \\
-\infty\end{array}$ & $\begin{array}{l}\text { ले } \\
\text { जे }\end{array}$ & $\infty$ & 岱 & $\infty$ & 告 & స్సે & $\begin{array}{l}\stackrel{0}{1} \\
\text { ind } \\
\end{array}$ & $\begin{array}{l}\widehat{N} \\
\infty \\
\infty \\
\infty\end{array}$ \\
\hline تِ & $\begin{array}{l}\overrightarrow{7} \\
\stackrel{8}{\circ}\end{array}$ & 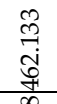 & 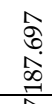 & 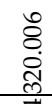 & 拿 & $\begin{array}{l}\text { तु } \\
\text { ठ্ं }\end{array}$ & $\begin{array}{l}m \\
0 \\
\dot{I}\end{array}$ & $\begin{array}{l}\stackrel{8}{0} \\
\stackrel{8}{\Theta}\end{array}$ & $\begin{array}{l}\stackrel{0}{0} \\
\text { di }\end{array}$ & 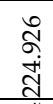 & 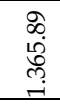 \\
\hline $0^{0}$ & $\mathbb{1}_{0}$ & $\infty$ & $\vec{m}$ & $\vec{\nabla}$ & $=$ & $\stackrel{\sigma}{-}$ & $\stackrel{0}{-}$ & $=$ & $\stackrel{\circ}{\circ}$ & ț & 8 \\
\hline
\end{tabular}

Directorate General of Migration Management, 2020a (In determining the data for 2020, the date of 15.09.2020 taken as a basis).

\section{Refugee and Asylum Seeker Migration}

Recently, refugee movements emerging especially in socio-economically less developed countries and originating from reasons such as poverty, conflicts and wars, natural disasters, and cultural oppressions have had an impact on the global scale. It is possible to consider Turkey, which is a part of the global system, among the countries exposed to refugee movements because of economic, cultural, political and historical reasons primarily con- 
nected to its geographical location. In fact, refugee migrations caused by socio-political developments as well as conflict and political turmoil in the nearby countries can easily be observed in the migration profile in Turkey. For instance, USSR's invasion of Afghanistan since 1979, regime change in Iran at the same period, Iran-Iraq war continued in 1980s, the dissolution of the Soviet Union in the 1990s, public movements called "Arab Spring" since 2010 and lastly Syrian civil war started in 2011 and continued till today altogether constitute an important aspect of this issue (Şişman \& Balun, 2020, pp. 63). Following the aforementioned negative developments, millions of migrant groups are seeking refugee in Turkey in order to get benefitted from international protection rights. The information provided in Table 10 shows that approximately 4 million people applied for temporary protection and 500 thousand people applied for international protection in the 2011-2020 period. When the source of these two types of refugee applications are considered, it is understood that they are mostly from Syria, Afghanistan, Iraq and Pakistan, located in the east of Turkey, where instability is intense for various reasons. In fact, these numbers are continuing to increase regularly. Within this respect, it is observed that the number of temporary protection applications, which was 14.237 in 2012 has reached up to 4 million in 2020. Movements similar to the temporary protection applications are seen in the international protection applications too. International protection applications which were 17.925 in 2011 reached up to 112.415 in 2017 and to 114.537 in 2018 (Table.10).

Table.10. Refugee and Asylum Seeker Migration (2011-2020)

\begin{tabular}{lcccccccccc}
\hline \multicolumn{1}{c}{} & $\mathbf{2 0 1 1}$ & $\mathbf{2 0 1 2}$ & $\mathbf{2 0 1 3}$ & $\mathbf{2 0 1 4}$ & $\mathbf{2 0 1 5}$ & $\mathbf{2 0 1 6}$ & $\mathbf{2 0 1 7}$ & $\mathbf{2 0 1 8}$ & $\mathbf{2 0 1 9}$ & $\mathbf{2 0 2 0}$ \\
\hline $\begin{array}{l}\text { Temporary } \\
\text { Protection }\end{array}$ & 0 & 14.237 & 224.655 & $\begin{array}{c}1.519 . \\
286\end{array}$ & $\begin{array}{c}2.503 . \\
549\end{array}$ & $\begin{array}{c}2.834 \\
441\end{array}$ & $\begin{array}{c}3.426 . \\
786\end{array}$ & 3.623 .192 & 3.576 .370 & 3.619 .918 \\
\hline $\begin{array}{l}\text { International } \\
\text { Protection }\end{array}$ & 17.925 & 29.678 & 30.311 & 34.112 & 64.232 & 66.167 & 112. & 114.537 & 56.417 \\
\end{tabular}

Directorate General of Migration Management, 2020b (In determining the data for 2020, the date of 16.09.2020 taken as a basis). 


\section{Conclusion and Evaluation}

International migration movements have become global. The number of individuals involving in the migration process is continuously increasing because of the reasons such as wars, civil conflicts, education, health, ecological conditions, disasters, religious oppressions, and discrimination. Today there is a mobile mass of migrants whose number is expressed with hundreds of millions. Migration is no longer a regional problem with the impact it has on both refugee and voluntary migration and it has become a phenomenon which requires internationally synchronized solutions. Increasing world population and in return increasing uneasiness and insufficiency of natural resources will expand the impact area of the migration more. Therefore, considering that the emerging impact will be limited to a certain region or country will further delay the solutions to the problems.

In order to reduce the effects of the ecological shocks in the future, it is of great importance to increase the resistance level of the more vulnerable countries. This approach will enable countries to be better prepared for the shocks and also will open the way to further strengthen their institutional structures in order to deal with the after-effects of these shocks. Moreover, ecological shocks are not only the problem of vulnerable countries but they also concern the countries that will face the ecological threats at lower levels. In fact, although countries with high resistance levels seem to have the capacity to deal with the ecological threats, mass refugee migrations are thought to affect these countries as well.

Individuals who have to leave or are forced to leave their countries due to reasons such as natural disasters, wars and internal conflicts, economic uncertainties, and political instabilities are important contributors to the global migration movements. These people who need international protection because of the negative conditions they have been exposed to constitute the refugee and asylum seeker population. Generally, this population who enters the hosting country illegally because of the negative conditions they are exposed to, have a special status according to international agreements. Basic documents defining special status of the refugees and asylum seekers at the legal level in the international arena are 1951 The Geneva Convention and the 1967 Protocol Relating to the Status of Refugees. Problems of the refugees needing international protection are tried to be solved with these 
international documents and national documents regulating the rights of the refugees. At this point, when the international protection regime of Turkey is taken into consideration, the weight of Middle Eastern countries such as Syria, Afghanistan and Iraq rather than European countries stand out in the applications for temporary protection and international protection. These countries remain out of the 1951 Geneva Convention, on the international position of refugees, which Turkey is also a party to but does not recognize the right of refugees outside Europe. Since the agreement in question was put into effect with a geographical reservation, the refugee applicants from the Middle East and Asian countries are also restricted. With the geographical reservation in the agreement dated 1951, Turkey tried to refrain from the socio-economic effects that migrant movements out of Europe would cause. This strategy could be a reasonable choice for the period when the Geneva Convention came to act, however, recent migration movements show that conditions have changed. After all, due to the geographical limitations, Turkey cannot provide temporary international protection for those coming from countries other than EU member countries and seeking asylum, therefore the people in these groups cannot have refugee status. At the same time, concepts in the national regulation are different because of the geographical limitations and therefore refugee groups that are defined separately but have different rights are emerging. (For instance, Refugee, asylum seeker, temporarily protected, subsidiary protection owner, conditional refugee). These approaches are thought to be creating inconveniences in the migration management system.

In the recent years, because of its geographical location, Turkey has been shifted to the "transit" and "target" country position for the irregular migrants. According to the data from Directorate General of Migration Management, 1.365.892 irregular migrants, in other words illegal migrants have been caught in the last 7 years. This situation has also increased the interest in migrant smuggling. In fact, illegal migration has changed its dimension today, and it has become an activity area where organized crime organizations direct and manage the illegal migration. When the subject is assessed within this respect, it is understood that the need for institutional substructure and the legislation that will answer the current requirements in the irregular and regular migration field is still ongoing. From which perspective Turkey will handle the migration issue and how it will define its position 
within the global migration system is particularly important in the process of determining policies and legislation. For instance, researches carried out show that a great majority of migrants in Turkey are employed with low wages, without a social security or protection and mostly in the sectors that do not need qualifications. It is thought that insufficient border security precautions, flexible visa policies, and problems in the inspections for occupational health and safety increase the number of foreigners coming to Turkey to work and encourage unregistered work. Therefore, it can be stated that in the regulations regarding the visa, residence and work permits, the relations between the informal economy and unregistered employment of the migrants should be taken into consideration.

Although there are strong arguments on Turkey becoming a transit migration base, its target (or destination) country position is also getting stronger. Only approximately 4 million Syrian refugees under the temporary protection status can be shown among the evidences of Turkey's being a target country. Moreover, when other groups seeking international protection and irregular migrants are included in this number, it becomes a mass with around 5 million populations. Also, it is observed that this number is increasing regularly over the years and it is thought that both transit and the target country position of Turkey will be more strengthened and debates on the issue will continue too.

\section{Acknowledgement}

This study is the expanded and revised version of the published abstract summary presented at the IV. International Applied Social Sciences Congress (C-IASOS 2020) Congress held on 22-24 October 2020 in Kuşadası).

\section{References}

Directorate General of Migration Management. (2013). Turkey migration report. https:/www.goc.gov.tr/kurumlar/goc.gov.tr/YillikGocRaporlari/2013 yillik goc raporu.pdf Access on 11.08.2020.

Directorate General of Migration Management. (2014). Turkey migration report. https://www.goc.gov.tr/kurumlar/goc.gov.tr/YillikGocRaporlari/2014 yillik goc raporu.pdf Access on 11.08.2020. 
Directorate General of Migration Management. (2015). Turkey migration report. https://www.goc.gov.tr/kurumlar/goc.gov.tr/YillikGocRaporlari/2015_yillik goc raporu.pdf Access on 11.08.2020.

Directorate General of Migration Management. (2016). Turkey migration report. Access on 11.08.2020.https://www.goc.gov.tr/kurumlar/goc.gov.tr/YillikGocRaporlari/2016 yiik goc raporu haziran.pdf Access on 11.08.2020.

Directorate General of Migration Management. (2020). Statistics. https://www.goc.gov.tr/giris-cikis Access on 11.08.2020.

Directorate General of Migration Management. (2020a). Irregular migration. https://www.goc.gov.tr/duzensiz-goc-istatistikler Access on 19.08.2020.

Directorate General of Migration Management. (2020b). Temporary protection and international protection. https://www.goc.gov.tr/gecici-koruma5638 Access on 19.08.2020.

Düvell, F. (2018). The "great migration" of summer 2015: Analysing the assemblage of Key Drivers in Turkey. Journal of Ethnic \& Migration Studies, 1-8.

Foreigners and International Protection Law. (2013). Republic of Turkey Official Gazette, No: 28615, 11 April 2013.

Institute for Economics \& Peace. (2020). Ecological threat register 2020: Understanding ecological threats, resilience $\mathcal{E}$ peace. Sydney, September. http://visionofhumanity.org/reports Access on 12.08.2020.

International Labour Law. (2016). Republic of Turkey Official Gazette. No: 29800, 13 August 2016.

International Organization for Migration. (2017). Mixed migration flows in the Mediterranean and Beyond. Flow Monitoring Data Analysis, International Organization for Migration, July.

International Organization for Migration. (2020). Global migration trends. https://www.iom.int/global-migration-trends Access on 25.09.2020.

İçduygu, A. (2005). Transit migration in Turkey: Trends, patterns and issues. CARIM Euro-Mediterranean Consortium for Applied Research on International Migration, Research Reports, CARIM-RR 2005/04, 1-4.

İçduygu, A., Sert, D. and Biriz Karaçay A. (2009). Briefing on Migration and AsylumSeeking Movements to Turkey and Relevant Policies. Migration Research Program at Koc University, 1, 1-7.

İçduygu, A. and Yükseker, D. (2010). Rethinking transit migration in Turkey: Reality and Re-presentation in the Creation of a Migratory Phenomenon. Population, Space $\mathcal{E}$ Place, 18, 441-443. 
Frontex. (2019). Risk analysis for 2019. Warsaw: Frontex Risk Analysis Unit, Reference Number: 1218/2019, February.

Ministry of Development. (2014). Migration specialization commission report. Ankara:Ministry of Development 10st Development Plan 2014-2018, Reference Number: KB: 2858 - ÖIKK: 712.

Ministry of Family, Labour and Social Services. (2018). Work permits for foreigner: 2018. https://ailevecalisma.gov.tr/media/31746/yabanciizin2018.pdf Access on 19.07.2020.

Nord, M., Andrews, M. and Carlson, S. (2006). Household food security in the United States, 2005. Economic Research Report, United States Department of Agriculture, Economic Research Service, No. 29, 6.

Şişman, Y. and Balun, B. (2020). Transit migration and Turkey. Journal of Anadolu University Faculty of Economics and Administrative Sciences, 21 (2), 61-79.

United Nations (2013). International migration policies government views and priorities. New York: Department of Economic and Social Affairs Population Division, ST/ESA/SER. A/342.

United Nations. (2018). Global migration indicators: 2018. Berlin: Global Migration Data Analysis Centre (GMDAC).

United Nations. (2019). International migration 2019. New York: Department of Economic and Social Affairs Population Division, ST/ESA/SER. A/439.

United Nations High Commissioner for Refugees. (2017). Global trends Forced Displacement in 2017. https://www.unhcr.org/5b27be547.pdf Access on 12.10.2020.

Wissink, M., Düvell, F. and Eardewijk, V., E. (2013). Dynamic Migration Intentions and the Impact of Socio-Institutional Environments: A Transit Migration Hub in Turkey. Journal of Ethnic and Migration Studies, 39 (7), 1088-1089.

\section{Kaynakça Bilgisi / Citation Information}

Balun, B. (2021). Global migrations and Turkey. OPUS-International Journal of Society Researches, 17(36), 2992-3014. DOI: 10.26466/opus.833619 